\title{
GOLD GEOCHEMISTRY AND MINERALOGY OF TILL FINES: A NEW APPROACH FOR DATA INTEGRATION
}

\author{
VLADIMIR KNAUF, ESA SANDBERG, PAVEL SOKOLOV and ERIK TABUNS
}

KNAUF, VLADIMIR, SANDBERG, ESA, SOKOLOV, PAVEL and TABUNS, ERIK 2000. Gold geochemistry and mineralogy of till fines: a new approach for data integration. Bulletin of the Geological Society of Finland 72, Parts 12, 57-69.

A new method of heavy mineral (HM) separation and assessment of gold grade was compared with the results of conventional AAS analysis. Sixteen gold micronuggets and a number of particles of native metal and metal alloys (brass, tin, bismuth, lead) were extracted from $100 \mathrm{~g}$ of till fines $(<50 \mu \mathrm{m})$. From the size, number, and composition of micronuggets, the total gold grade (58 ppb) of till fines was evaluated. The assessments agree well with the results of AAS analysis ( $57 \mathrm{ppb}$ ). A slightly lower value (44 ppb) was obtained by Flame Atomic Absorption Analysis with Fire Assay (FAAS FA) method of the extracted HM. Mineralogical investigations allow identification of two types of gold micronuggets thus revealing a complex origin for the geochemical anomaly. The association of brass-pyroxene (Mg\# = 80-82) with complex gold-brass-lead-tin intergrowths indicates that some gold in till is derived from ultramafic rocks.

Key words: geochemical methods, till, fines, gold, bismuth, copper, lead, tin, metals, alloys, ore grade, mineralogy

Vladimir Knauf and Pavel Sokolov: P.B. NATI \& “FIP-BIS” Co. Ltd, P.O. Box 41, St.Petersburg, Russia, 197136.

E-mail: sokolovp@mail.ru

Esa Sandberg: Outokumpu Mining Oy, Tehtaankatu 2, FIN-83500 Outokumpu, Finland.

E.V. Tabuns: Department of Geochemistry, St.Petersburg State University, University emb. 7/9, St.Petersburg, Russia, 199034.

E-mail: erik@ET2057.spb.edu

\section{INTRODUCTION}

Accessory heavy mineral analysis of till provides a useful tool for verifying any decision made during geochemical exploration for gold. It gives supplementary information about the mode of occurrence of gold, nugget transport distance and, ulti- mately, about the origin of the element dispersion halo.

In Finland, the fine fraction of till is used usually in geochemical exploration. In this case, because of the small grain size, it is possible to use a small sample weight and to some extent eliminate reduction and secondary subsampling er- 
rors. For exploration mineralogists, the key problems arise from the low concentration thresholds of gold anomalies and the small particle size. Conventional methods (panning, heavy liquid separation) are only capable of extracting relatively coarse mineral grains while the low gold content requires large samples. Consequently, geochemists and mineralogists use different approaches in investigating gold in different till fractions and this presents a major problem in the accurate interpretation of data.

In this paper, we present a new effective method for heavy mineral extraction from till fines. The main objectives of this study were: (i) to examine the usefulness of the new heavy mineral separation technology in gold prospecting; (ii) to compare direct mineralogical gold content measurements with geochemical data and to estimate $\mathrm{Au}$ distribution homogeneity in the samples, and (iii) to evaluate gold micronugget composition and morphology in till fines.

\section{METHODS}

Two glacial till samples, S-8 and S-9, from the Isovesi gold prospect, Suodenniemi, located in the northwestern part of the Tampere Schist Belt, were investigated. The samples were collected in June 1997 by tractor-excavator during the geochemical study of the area. The first sample, S- 8 , is from a layer of washed water lain till at a depth of $1 \mathrm{~m}$. The site is located in the highest nugget anomaly area of the prospect. The second sample, S-9, from basal, unwashed till at a depth of $3 \mathrm{~m}$ is located in the gold anomaly area of the fine till fraction. Both samples are close to the bedrock surface and the sites are about $200 \mathrm{~m}$ apart.

The bedrock of the area consists mainly of intermediate metavolcanics with skarn layers and spots and is cut by narrow shear zones that host native gold and electrum with arsenopyrite, pyrrhotite, pyrite and chalcopyrite (Luukkonen 1994). No economic gold deposits have yet been discovered in the area.

A general outline of the sample processing is given in the flowchart in Fig. 1. For mineralogi- cal investigations, samples were dried at $100^{\circ} \mathrm{C}$ and dry-sieved to yield fine $(<50 \mu \mathrm{m})$ fractions. Heavy minerals together with gold micronuggets were then extracted from these fines using a special mineral separation technique (Knauf 1996, Knauf \& Sendeev 1996). This method allows the separation of fine ore mineral particles that have a wide range in specific gravity in water media. The procedure is performed in a closed system, which makes it possible to avoid contamination and to check each step in the process, and to achieve high sensitivity and low detection limits.

Generally, the recovery of gold depends on the sample type (e.g. grain size, mineralogy, appearance), on the heavy mineral enrichment factor (upgrading), and the mode of separation (Fig. 2). All the work reported here was performed using relatively low upgrading (180-830 fold heavy mineral enrichment) and was accompanied with around $30 \%$ losses, most of which are related to intergrowths and the finest $(<5 \mu \mathrm{m})$ gold micronuggets.

Heavy mineral fractions were extracted from three S-8 subsamples $(<50 \mu \mathrm{m})$ for mineralogical investigations and the direct assessment of gold grade. Following this, special polished sections were prepared carefully from all the extracted grains. Gold and other micronuggets of native metal were further identified and analysed for major components by electron microprobe. The investigation of other heavy minerals was beyond the scope of our research.

The total gold content $\left(\mathrm{C}_{\mathrm{Au}}\right)$ in sample was calculated with the formula:

$\mathrm{C}_{\mathrm{Au}} \cong\left[\Sigma\left(\mathrm{V}_{\mathrm{i}} \times \mathrm{Di} \times \mathrm{F}_{\mathrm{i}} / 1000\right)\right] /(\mathrm{k} \times \mathrm{M})$,

where $V_{i}, D_{i}$ and $F_{i}$ denote the estimated volume, specific gravity and the fineness of a particular gold grain, respectively; $M$ is the sample weight, and $\mathrm{k}$ is the factor of extraction (for the samples studied, $\mathrm{k}=0.7$ ).

In order to verify the completeness of gold recovery, three additional heavy mineral duplicates were prepared using lower upgrading (Fig. 1). Afterwards, these samples were analysed for gold in a commercial laboratory using Flame Atomic 
Fig. 1. Flowchart for sample S-8 processing.

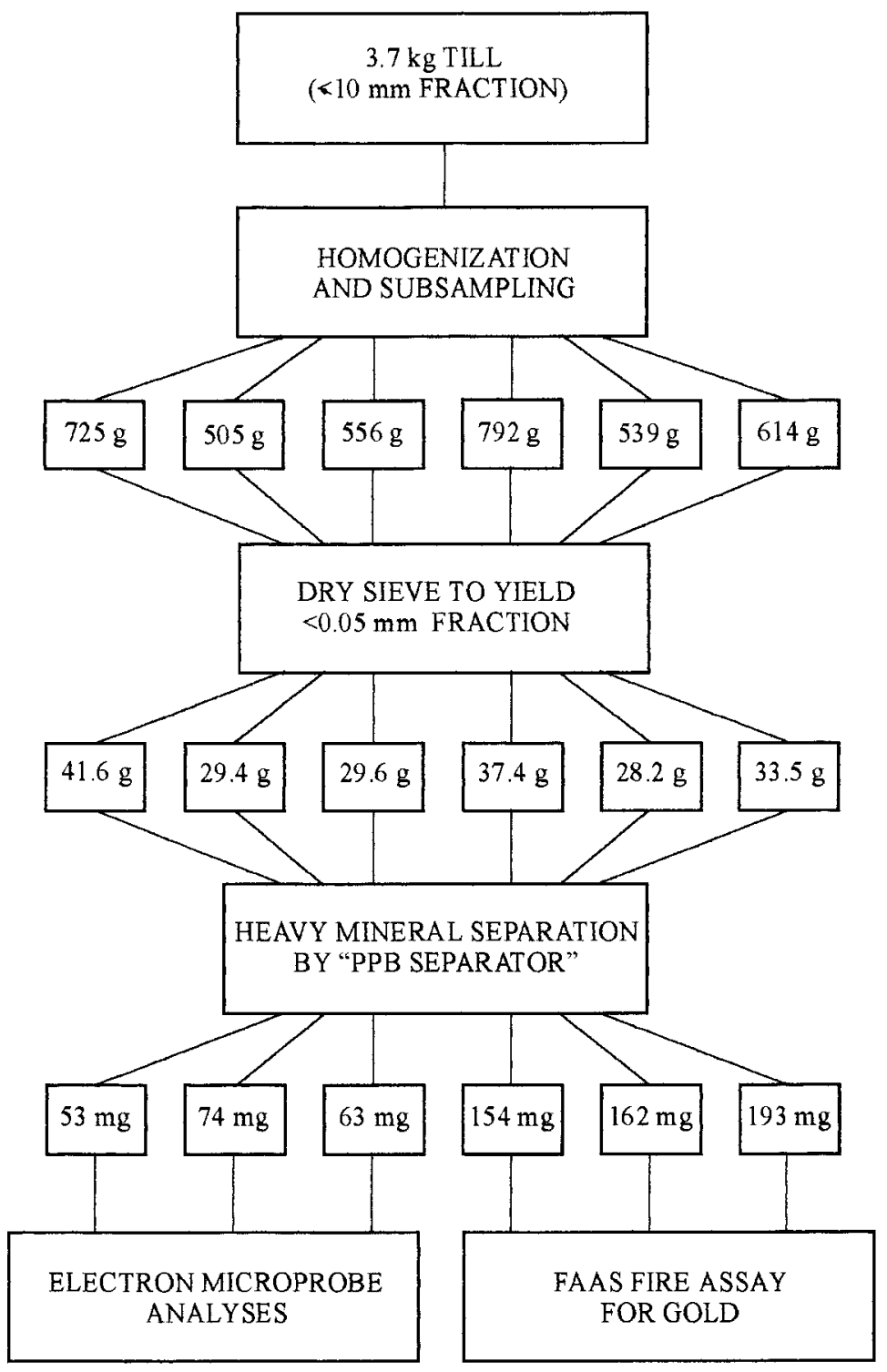

Absorption Spectroscopy with Fire Assay fusion and lead collection (FAAS FA).

Electron microprobe analyses were made using an ABT-55 (Atashi Beam Technology) equipment with a LINK 10000 energy-dispersive analyser under routine operation conditions: $20 \mathrm{KeV}$ accelerating potential, a specimen current of 0.5 nanoampers and pure element standards. A ZAFcorrection procedure was used to adjust the analytical results.

\section{RESULTS}

\section{Mineralogy}

Sixteen gold micronuggets were extracted from till sample S-8 (Figs. 3a-d). Their effective size (diameter of sphere equal in volume with estimated grain volume) varies from $6 \mu \mathrm{m}$ up to $31 \mu \mathrm{m}$. Ten particles and particle intergrowths of native copper, tin, lead and brass, and $\mathrm{Pb}-\mathrm{Sn}, \mathrm{Sn}-\mathrm{Pb}$ and $\mathrm{Sb}-$ $\mathrm{Sn}$ alloys were also identified. Of particular inter- 


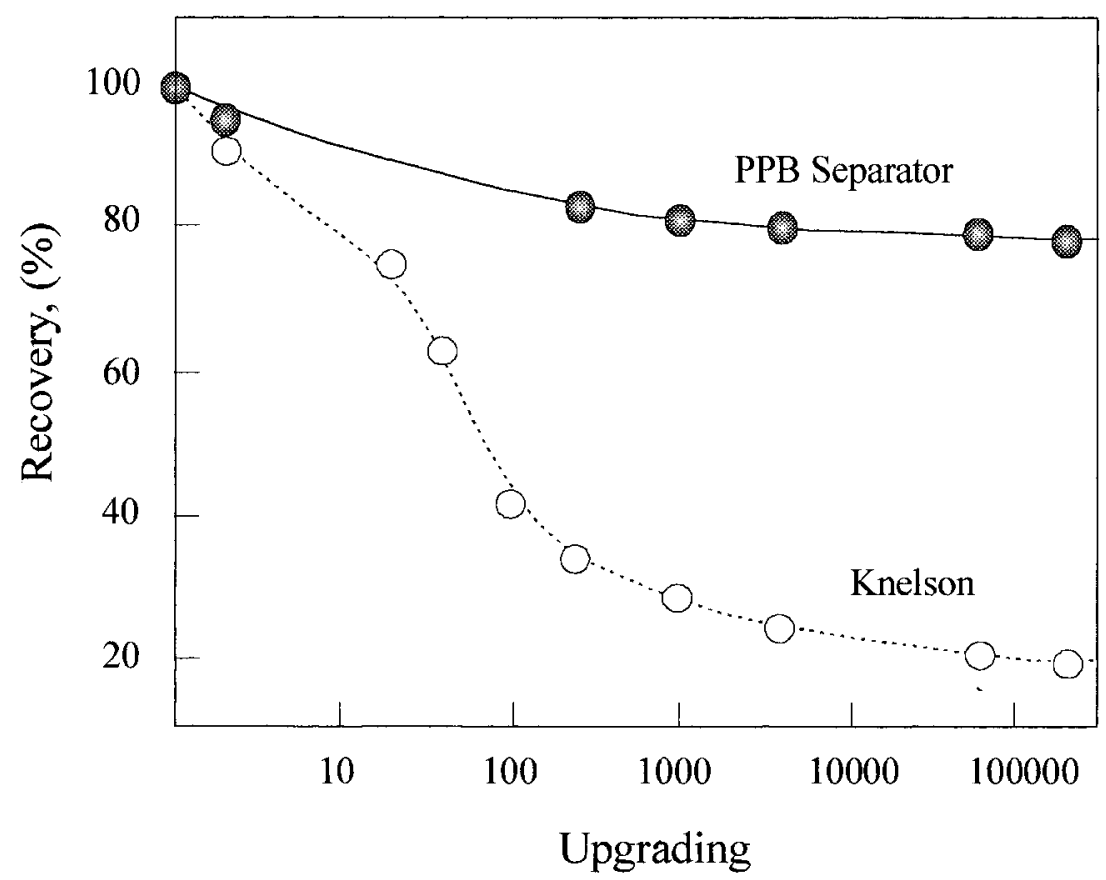

Fig. 2. Diagram of recovery vs. grain size. est are a native brass intergrowth with two pyroxene lamellae (Fig. 3c-2) and a small $10 \mu \mathrm{m}$ composite particle that has gold, native brass, tin and lead intergrowths (Fig. 3d-6).

The results of microprobe measurements for the main components are listed in Table 1. The data presented show that the fineness of the gold particles ranges from 731 to 998 . In practice, considering gold composition only, it is possible to recognise three types of particles: (i) almost pure gold with a fineness of 997-998, (ii) gold with a fineness of 844-948, and (iii) gold with a fineness of 731-794.

However, when the size and appearance of gold nuggets are also considered, another classification is possible. It is evident from Fig. 4 that all the grains can be divided into two groups. One group contains those grains with a rounded appearance and an effective size of more than $19 \mu \mathrm{m}$ and another group those with etched, flaky, indefinite shapes and a smaller size. In the latter group there is an inverse relationship between the size and fineness of grains. Furthermore, the microprobe data indicate that the larger particles have a higher $\mathrm{Cu}$ content, whereas the particles of gold- $\mathrm{Bi}_{2} \mathrm{~S}_{3}$
(Fig. 3b-2) and those with composite gold, native brass, tin and lead intergrowths (Fig. 3d-6) belong to the second group.

\section{Gold grading}

The results for gold content assessment of till fines ( $<50 \mu \mathrm{m}$ fraction) obtained by using the new heavy mineral separation technique are summarised in Table 2. There is some discrepancy between direct mineralogical and FAAS Fire Assay

Table 1a. Electron microprobe data (wt\%) for gold from subsample S8-1-1m (Fig. 3a).

\begin{tabular}{lcrrr}
\hline Picture\# & $\mathrm{Au}$ & $\mathrm{Ag}$ & $\mathrm{Fe}$ & Total \\
\hline 1 & 91.4 & 8.4 & - & 99.8 \\
1 & 92.3 & 7.4 & - & 99.7 \\
2 & 78.6 & 20.9 & - & 99.5 \\
3 & 93.5 & 6.3 & - & 99.8 \\
3 & 96.5 & - & 2.4 & 98.9 \\
3 & 94.4 & - & 5.0 & 99.4 \\
4 & 90.7 & 8.7 & - & 99.4 \\
5 & 86.9 & 12.7 & - & 99.6 \\
6 & 91.4 & 7.9 & - & 99.3 \\
7 & 78.7 & 20.9 & - & 99.6 \\
\hline
\end{tabular}



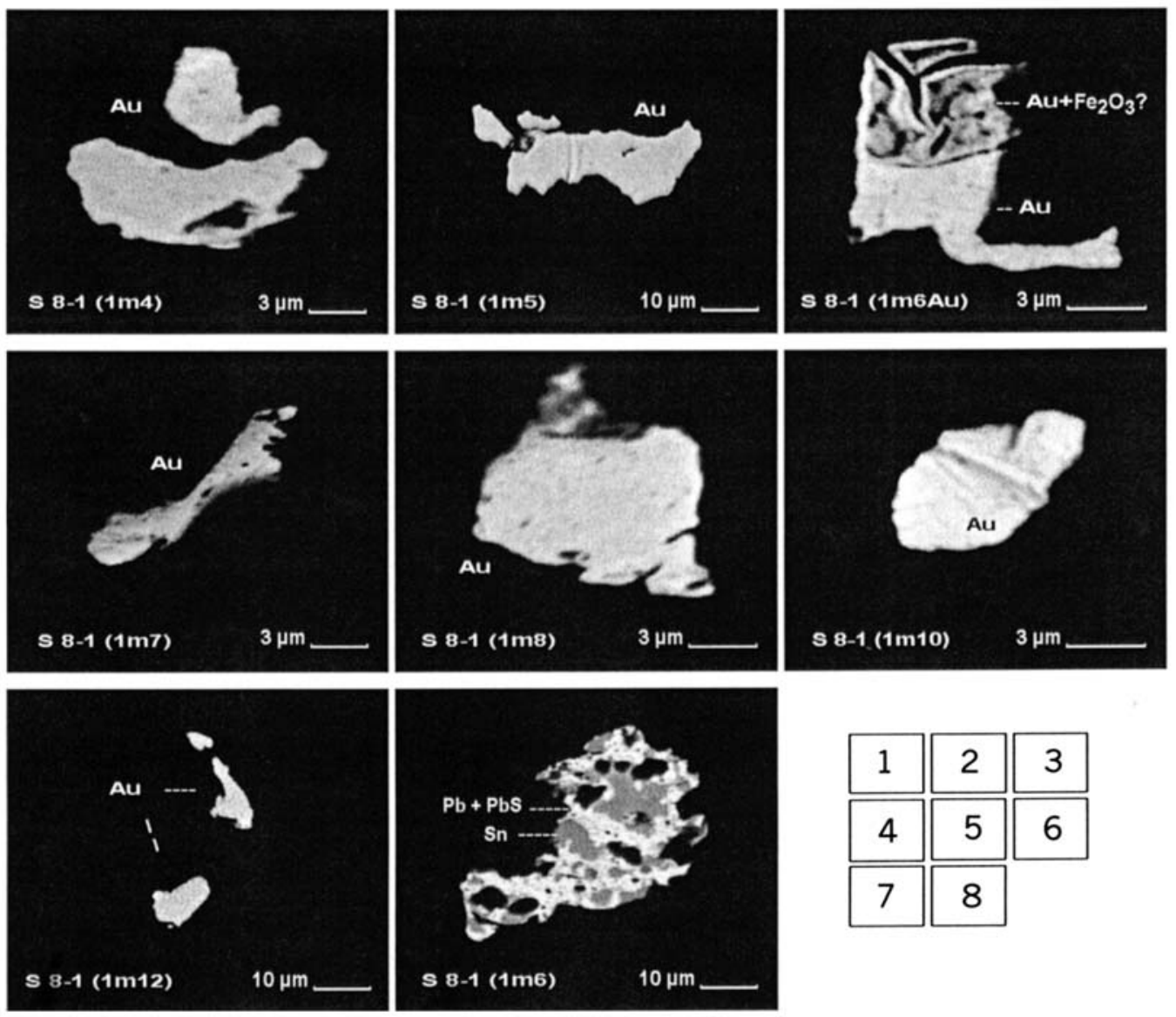

Fig. 3a. Back-scattered electron images of gold micronuggets and native metal alloy particles extracted from different $S$-8 subsamples.

estimates, but the differences are thought to be statistically insignificant and caused by sample heterogeneity. It is clear that Au micronuggets are

Table 1b. Electron microprobe data (wt\%) for gold from subsample S8-1-2m (Fig. 3b).

\begin{tabular}{lcrrr}
\hline Picture\# & $\mathrm{Au}$ & $\mathrm{Ag}$ & $\mathrm{Cu}$ & Total \\
\hline 1 & 84.2 & 15.4 & - & 99.6 \\
2 & 94.0 & 5.8 & - & 99.8 \\
2 & 94.1 & 5.8 & - & 99.9 \\
3 & 99.7 & - & - & 99.7 \\
4 & 78.9 & 20.6 & - & 99.7 \\
4 & 69.1 & 30.3 & 0.2 & 99.6 \\
4 & 71.2 & 28.1 & 0.1 & 99.4 \\
5 & 79.4 & 20.1 & - & 99.5 \\
6 & 99.8 & - & - & 99.8 \\
\hline
\end{tabular}

unevenly distributed in the till sample. The number of identified $\mathrm{Au}$ particles ranges from 3 to 7 in the different S 8-1 subsamples. The corre-

Table 1c. Electron microprobe data (wt\%) for native metals from subsample S8-1-2m (Fig. 3c).

\begin{tabular}{lrrrrrr}
\hline Picture\# & $\mathrm{Cu}$ & $\mathrm{Zn}$ & $\mathrm{Sn}$ & $\mathrm{Sb}$ & $\mathrm{Pb}$ & Total \\
\hline 1 & - & - & 43.4 & - & 55.8 & 99.2 \\
1 & - & - & 83.3 & 0.2 & 15.9 & 99.4 \\
2 & 63.1 & 36.6 & - & - & - & 99.7 \\
3 & 99.4 & - & - & - & - & 99.4 \\
3 & 63.8 & 35.7 & - & - & - & 99.5 \\
4 & 99.6 & - & - & - & - & 99.6 \\
5 & 2.4 & 1.5 & 92.1 & 3.6 & - & 99.6 \\
5 & 2.3 & 1.7 & 1.3 & - & 94.3 & 99.6 \\
5 & 56.7 & 37.2 & 5.2 & - & - & 99.1 \\
6 & 63.0 & 36.4 & - & - & - & 99.4 \\
\hline
\end{tabular}


1

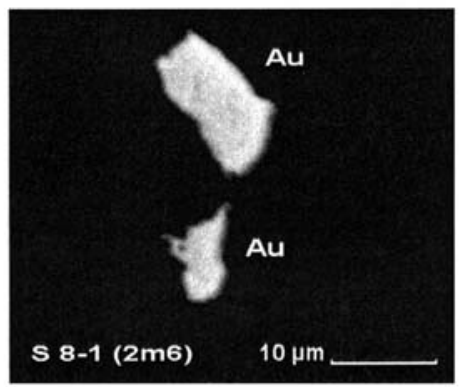

3

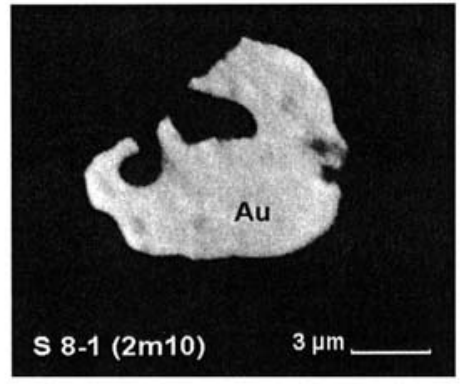

5

Fig. 3b.
2

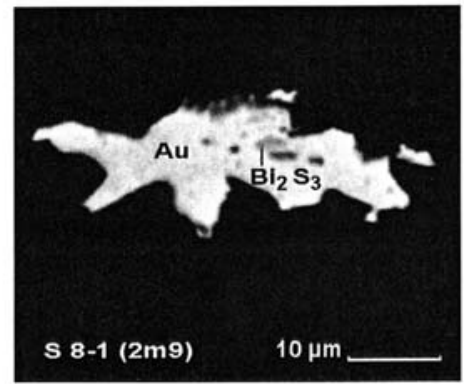

4

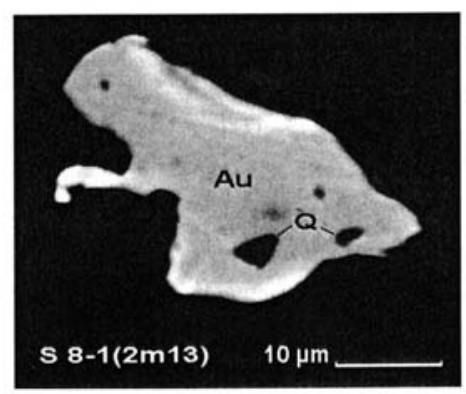

6

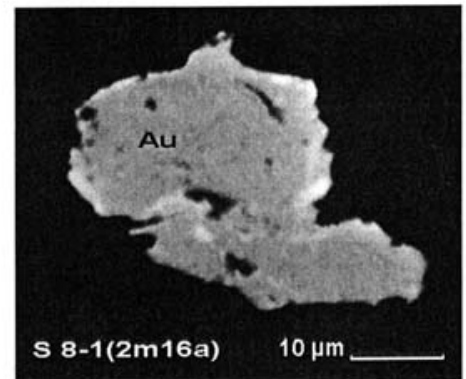

Table 1d. Electron microprobe data (wt\%) for gold and other native metals from subsample S8-1-3m (Fig. 3d).

\begin{tabular}{lrrrrrrrr}
\hline Picture\# & $\mathrm{Au}$ & $\mathrm{Ag}$ & $\mathrm{Cu}$ & $\mathrm{Zn}$ & $\mathrm{Sn}$ & $\mathrm{Sb}$ & $\mathrm{Pb}$ & Total \\
\hline 1 & 87.4 & 11.6 & 0.5 & - & - & - & - & 99.5 \\
1 & 83.6 & 16.1 & - & - & - & - & - & 99.7 \\
2 & 91.3 & 83. & - & - & - & - & - & 99.6 \\
3 & 88.4 & 11.2 & - & - & - & - & - & 99.6 \\
4 & - & - & 0.7 & 0.3 & 92.8 & 0.8 & 4.1 & 98.7 \\
4 & - & - & - & - & 19.2 & 0.2 & 80.4 & 99.8 \\
5 & - & - & 62.8 & 36.3 & - & - & - & 99.1 \\
5 & - & - & 9.9 & 2.9 & 29.3 & 12.5 & 43.8 & 98.4 \\
6 & 86.4 & 11.7 & 0.2 & - & 1.5 & - & - & 99.8 \\
6 & - & - & 63.3 & 35.2 & 0.2 & 0.1 & 0.5 & 99.3 \\
\hline
\end{tabular}


1

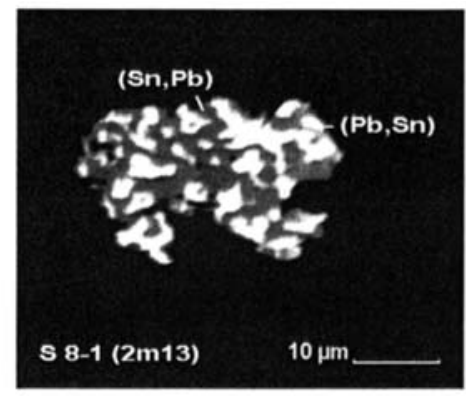

3

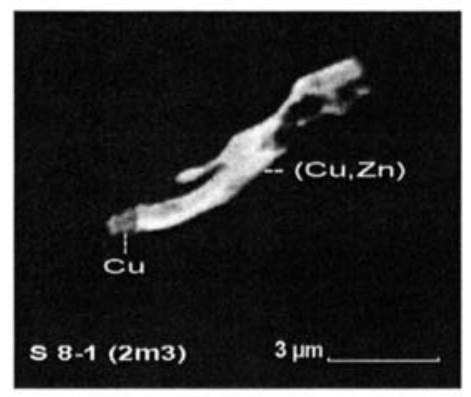

5

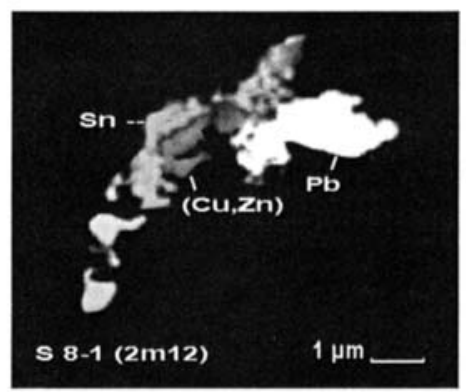

2

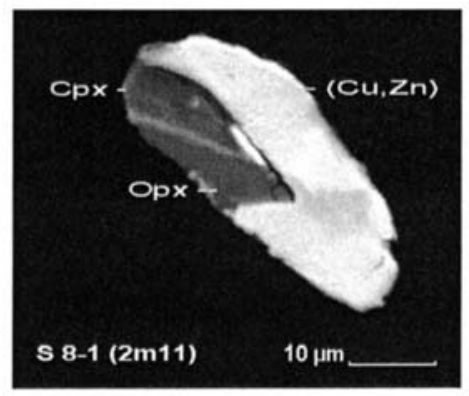

4

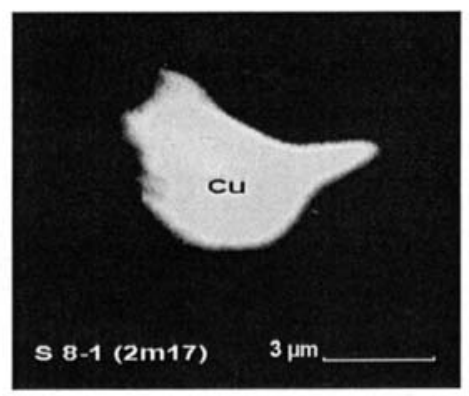

6

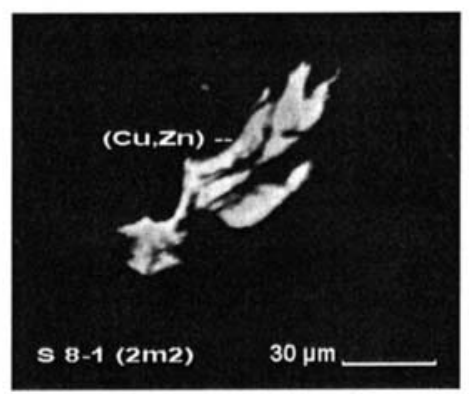

sponding calculated Au content varies between 36 and $99 \mathrm{ppb}$ and is on average $58 \mathrm{ppb}$. It may be assumed that approximately $5.6 \mathrm{~g}$ of the till fines investigated contains one gold particle.

Generally, the total gold grade of the glacial till samples was evaluated using five different, nearly independent techniques. Three of them were conventional: (i) analysis of till fines $(<60 \mu \mathrm{m}$ fraction), and (ii and iii) extraction of heavy minerals by panning and by cyanide leaching of a $<10 \mathrm{~mm}$ fraction. Table 3 lists the results of these determinations together with the gold grade assessments obtained using the new separation meth- od. For comparison, the results from sample S9 are also included in Table 3 . There is a slight difference between the total grade assessment obtained by the Geological Survey of Finland (GTK) and that obtained in the present study by FAAS FA analyses of extracted HM fractions.

\section{DISCUSSION}

Exploration geochemists are well aware of the problems related to $\mathrm{Au}$ content quantification at the ppb level. It is generally agreed that uneven 


\section{1}

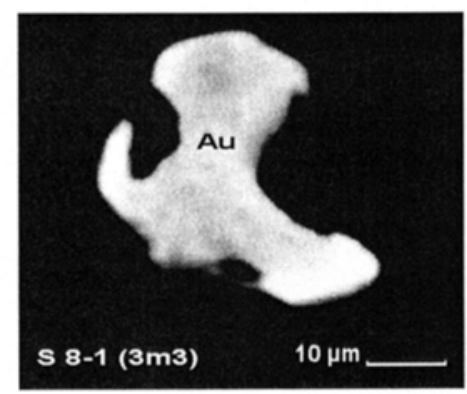

3

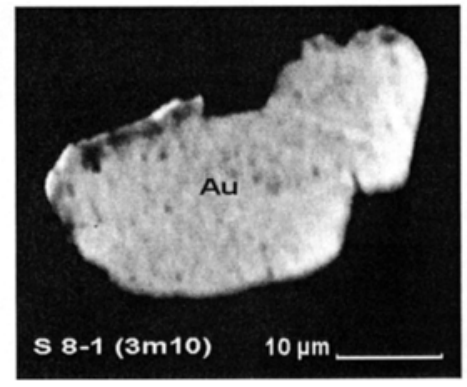

5

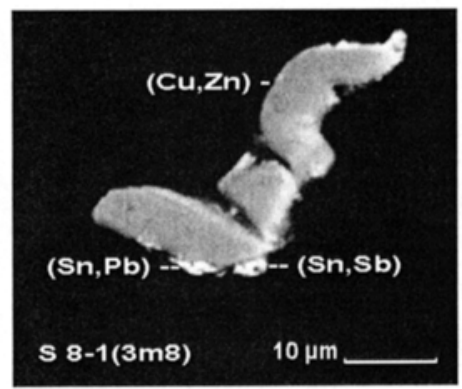

s-1(3m8)
2

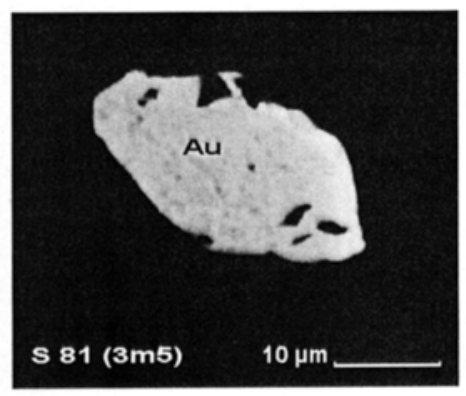

4

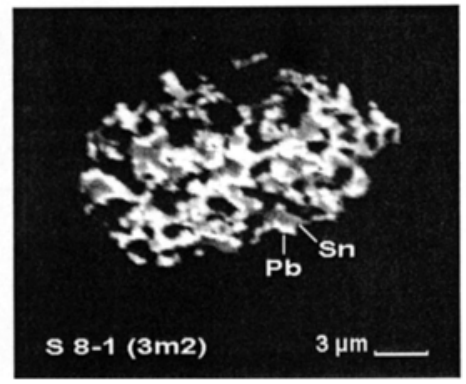

6

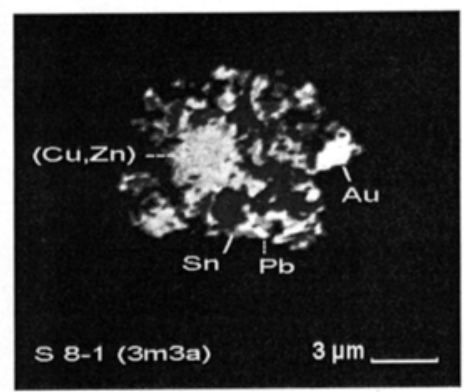

8-1 (3m3a)

Fig. 3d.

fect violates the general principle of exploration geochemistry: the greater the ore component concentration, the closer the ore.

Poor data reproducibility (i.e. low correlation coefficients between two sets of same samples) is another consequence of the same effect. It clearly is the reason for the poor correlation of Au with other elements, even with those geochemically similar. Therefore it is not unexpected, that in places Au itself is the only pathfinder element for gold ores.

Recently, Cook (1997) has compared the results of the gold assessment in the lake sediment sam- 
Fig. 4. Plot of gold content vs effective grain size for gold micronuggets extracted from till fines (sample S8-1; 50 um fraction).

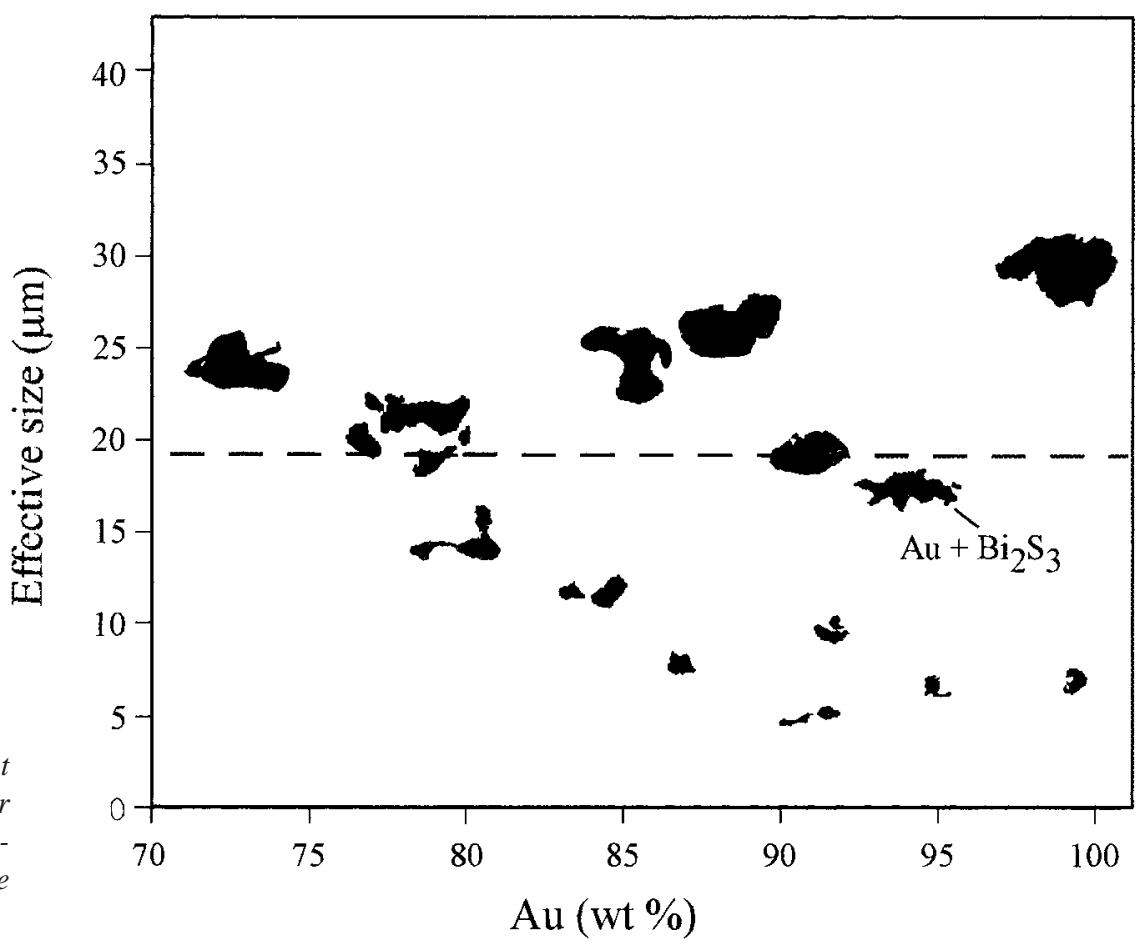

Table 2. The results of gold content assessment in the till fines ( $<50 \mu \mathrm{m}$ fraction) by using the new heavy mineral separation technology.

\begin{tabular}{|c|c|c|c|c|c|c|c|c|}
\hline Subsample & Tot. wt., g & $\begin{array}{l}\text { Fraction } \\
<50 \mu \mathrm{m}, \mathrm{g}\end{array}$ & HMF, $\mathrm{g}$ & $\begin{array}{l}\text { Number of } \\
\text { Au particles }\end{array}$ & $\begin{array}{l}\mathrm{Au}, \mu \mathrm{g} \\
\text { in } \mathrm{HMF}\end{array}$ & \multicolumn{3}{|c|}{$\begin{array}{c}\mathrm{Au}( \pm 1 \sigma) \text { in till fines } \\
\quad(<50 \mu \mathrm{m}), \mathrm{ppb}\end{array}$} \\
\hline S $8-1 / 1$ & 725.39 & 41.60 & 0.053 & 7 & $2.892^{\mathrm{a}}$ & 99.3 & & \\
\hline S $8-1 / 2$ & 504.94 & 29.44 & 0.074 & 6 & $1.366^{\mathrm{a}}$ & 66.3 & $70 \pm 28$ & \\
\hline S $8-1 / 3$ & 555.63 & 29.63 & 0.063 & 3 & $0.898^{a}$ & 43.3 & & \\
\hline Total & 1785.96 & 100.67 & 0.190 & 16 & 5.156 & & & $58 \pm 24$ \\
\hline S $8-1 / 4$ & 791.61 & 37.41 & 0.154 & n.d. & $0.950^{\mathrm{b}}$ & 36.3 & & \\
\hline S $8-1 / 5$ & 538.96 & 28.20 & 0.162 & n.d & $1.100^{\mathrm{b}}$ & 55.7 & $44 \pm 11$ & \\
\hline S $8-1 / 6$ & 614.22 & 33.46 & 0.193 & n.d & $0.910^{\mathrm{b}}$ & 38.9 & & \\
\hline Total & 1944.79 & 99.07 & 0.509 & n.d & 2.960 & & & \\
\hline S 9/1 & 365.57 & 53.39 & 0.325 & n.d & $0.76^{\mathrm{b}}$ & 20.5 & & \\
\hline S $9 / 2$ & 384.87 & 55.61 & 0.083 & n.d & $0.35^{\mathrm{b}}$ & 9.0 & $15 \pm 6$ & $15 \pm 6$ \\
\hline $\mathrm{S} 9 / 3$ & 398.47 & 54.36 & 0.229 & n.d & $0.61^{\mathrm{b}}$ & 16.1 & & \\
\hline Total & 1148.91 & 163.36 & 0.637 & n.d & 1.72 & & & \\
\hline
\end{tabular}

HMF - heavy mineral fraction obtained by PPB separator

a direct assessment taking into account $\mathrm{Au}$ particle number, size and fineness

b FAAS - Fire Assay of heavy mineral fraction

n.d - not determined

$\mathrm{ppb}$ - parts per billion 
Table 3. Comparison of gold grade assessment in till obtained by different techniques.

\begin{tabular}{|c|c|c|c|c|c|c|c|c|}
\hline \multirow[t]{2}{*}{ \# } & \multirow[t]{2}{*}{ Technique } & \multirow[t]{2}{*}{ Fraction } & \multirow[t]{2}{*}{ Analysed material } & \multirow{2}{*}{$\begin{array}{c}\text { Analitycal } \\
\text { method }\end{array}$} & \multicolumn{2}{|c|}{$\mathrm{Au}, \mathrm{ppb}(\mathrm{S} \mathrm{8-1)}$} & \multicolumn{2}{|c|}{$\mathrm{Au}, \mathrm{ppb}(\mathrm{S} 9)$} \\
\hline & & & & & till & HMF & till & HMF \\
\hline 1 & & $<60 \mu \mathrm{m}$ & till & AAS & 57 & - & 49 & - \\
\hline 2 & $\begin{array}{l}\text { Conventional } \\
\text { (GTK) }\end{array}$ & $<10 \mathrm{~mm}$ & $\begin{array}{l}\text { cyanide leach } \\
\text { from till }\end{array}$ & AAS & 36 & - & 23 & - \\
\hline 3 & & $<10 \mathrm{~mm}$ & HMF (panning) & AAS & - & 640 & - & 420 \\
\hline 4 & $\begin{array}{l}\text { "PPB - } \\
\text { mineralogy" }\end{array}$ & $<50 \mu \mathrm{m}$ & HMF (PPB-Sep) & EMP & 70 & 38767 & - & - \\
\hline 5 & & $<50 \mu \mathrm{m}$ & HMF (PPB-Sep) & FAAS FA & 44 & 8308 & 15 & 3073 \\
\hline
\end{tabular}

FAAS FA - Flame Atomic Absorption Spectroscopy with Fire Assay

HMF - heavy mineral fraction

EMP - electron microprobe

ples of various size. He has found that the weight doubling of field samples from $100 \mathrm{~g}$ up to $200 \mathrm{~g}$ does not improve the representativity and reliability of $\mathrm{Au}$ analyses whereas the relatively low reproducibility obtained $(\mathrm{r}=0.49$ between standard size and large sample duplicates for 34 sample pairs) demonstrates that the main errors arise from secondary laboratory sampling. The analytical $10 \mathrm{~g}$ subsample used in this investigation appears to be too small for reliable assessment of Au concentration. Consequently, in standard exploration practice, the nugget effect problem remains unsolved.

In the present example the Au content in six S-8 subsamples varies from 36 up to $99 \mathrm{ppb}$. An $\mathrm{Au}$ content of $58 \mathrm{ppb}$ in the total $200 \mathrm{~g}$ sample closely corresponds to the data obtained by conventional AAS at GTK (Table 3). This demonstrates that the nugget effect is the main cause of variations in $\mathrm{Au}$ content in subsamples. According to the 20 particle rule (Clifton et al. 1969) for a given particle size and Au concentration, the minimum laboratory sample weight for a reliable analysis is approximately $100 \mathrm{~g}$.

The next problem arises from poor gold recovery. Hall et al. (1989) have investigated 32 rock samples in 16 laboratories and have shown that the amount of gold remaining in the residue after aqua regia attack varies from $4 \%$ up to $59 \%$ of the total Au because of non-wetting of the samples, ineffective mixing during digestion and the protection of Au by unattacked gangue. In this respect, the PPB separation technique gives the same or- der of uncertainties as other methods, but is of benefit as it provides additional information concerning gold mineralogy. Nevertheless, it is clear from the above argument that there is good agreement between gold assessment obtained by the conventional method and that obtained by the new method. This agreement is remarkable given the differences in analytical methods, calibration techniques used and especially in the volume of material analysed.

Many investigations have demonstrated the presence of minute particles of native metals (Al, $\mathrm{Mg}, \mathrm{Zn}, \mathrm{Cu}, \mathrm{Sn}, \mathrm{Cr}, \mathrm{Ni}, \mathrm{Co}$ ) or metal alloys in different geological objects (magmatic rocks, sediments and ores). These observations have been mainly reported in the Russian literature (see reviews by Novgorodova 1983, Urusov et al. 1997). The simplest way to explain the occurrence of metals in the natural environment is derivation from artefacts. However, our experience with brass and solder devoid sample processing equipment excludes this possibility at least in the present investigations. An unusual pyroxene-brass intergrowth (Fig. 3c-2) extracted from till confirms this conclusion. However, the preservation of native metal particles in the natural environment remains an unresolved problem. Rough estimates made by Stockman and Hlava (1984) indicate that the most resistant $25 \mu \mathrm{m}$ pure Ni particle, when exposed to an oxidising environment, should last not more than 100 years. Urusov et al. (1997) suggest that their organic coating or specific small 
particle properties may prevent their destruction. Clearly the problem requires further specialised investigations. This is essential because the native metals extracted from the sample S 8-1 are related to gold occurrence as it is clearly indicated by an Au-Sn-Pb-brass intergrowth (Fig. 3d-6).

All native metal grains extracted from till fines range in morphology from well-rounded, almost homogenous alloys of $\mathrm{Cu}-\mathrm{Zn}$ and $\mathrm{Sn}-\mathrm{Pb}$ to patchy and hackly, friable-looking porous grains. The latter are similar to the placer gold rims with swiss cheese texture documented by Groen et al. (1990) or to porous $\mathrm{Ru}$-rich alloys in alpine chromitites (Stockman \& Hlava 1984). Several processes are thought to be responsible for their origin. According to Groen et al. (1990), self-electrorefining in tandem with dissolution-precipitation (cementation) is the process likely in the formation of swiss cheese rims around gold nuggets. Bird and Busset (1980) consider that porous Ru-Fe alloy particles may be the result of oxidizing weathering and leaching of pre-existing alloys. As proposed by Stockman and Hlava (1984), the porosity of Ru-rich alloys is an expected consequence of the changes in volume that result from the subsolidus reduction of a metal component from laurite grains during $\mathrm{H}_{2}$ production accompanying the hydrous alteration of peridotite. We consider that the same type of process may be responsible for the native metal origin in the investigated till. It is noteworthy that magnesium-rich pyroxenes $(\mathrm{Mg} \#=80$ 82) from a brass-silicate intergrowth indicate that brass and, probably, complex gold-brass-lead-tin particles are related to ultramafic peridotites or other mantle derived rocks (picrites, komatiites).

A number of studies indicate that the composition, size and appearance of gold nuggets can be used in assessing their transport distance and source (Halbauer \& Utter 1977, Giusti 1986, Groen et al. 1990, Grant et al. 1991, Vasconcelos \& Kyle 1991, Leon 1995, Youngson \& Craw 1995, Kinnunen 1996). The main data for gold micronuggets in the studied sample agree well with that obtained by conventional methods (Huhta 1989, Nikkarinen 1991). The sample preparation technique used in the present investigations precludes the accurate identification of gold par- ticle morphology necessary for categorisation of them according to existing complex classification (DiLabio 1990). Nevertheless, the mineralogical data obtained in this study is sufficient to demonstrate that gold in the anomalous sample S 8-1 has at least two sources of origin. Most of the gold consists of the larger rounded micronuggets. The smaller grains, and accordingly a lesser amount of gold, are related to other source rocks. Considering the association of minute Au particles with native brass, the most probable source candidate for these are the still unknown ultramafic rocks of the Tampere Schist Selt. An accurate solution for the problem requires further mineralogical studies of HM from the bedrock and ore mineralization zones of the region.

\section{CONCLUSIONS}

The benefits of the PPB separation technique became known during this study. Regarding quality and reliability, the gold grade assessment obtained compares well with that measured by conventional element analysis. To achieve accurate target mapping during further exploration, it will be necessary to assess the content of two type gold micronuggets in all samples from the anomalous zone represented by sample S 8-1.

The results presented above show that the new heavy mineral separation method has several advantages over others:

- the size of sample and heavy mineral separation conditions could be varied over a wide range to attain the required reliability and detection limits as well as to eliminate nugget effect and secondary sampling errors,

- it is possible to conduct simultaneous geochemical and mineralogical investigations from one subsample split from the finest till fraction,

- the simultaneous determination of total gold grade, micronugget size, appearance, and composition gives an insight into the origin of geochemical anomalies and thus allows the identification of those that are false.

It is clear that the method is a useful tool in geo- 
chemical gold exploration and should be further tested and used in different geological conditions.

ACKNOWLEDGEMENTS. The authors wish to thank the ever helpful staff of Outokumpu Mining Oy, especially Eero Soininen and Eero Rauhamäki, for their kind assistance. We are very grateful to Lauri Pekkarinen for fruitful discussions. We thank Dr. R.N.W DiLabio, Dr. Kari A. Kinnunen, Dr. V.G. Krivovichev, and Dr. S.B. Sergeyev for their critical comments on an early version of this manuscript. The study was financed by the "FIP-BIS" Co. Ltd.

\section{REFERENCES}

Bernier, M.A. \& Weber, G.R. 1989. Mineralogical and geochemical analysis of shallow overburden as an aid to gold exploration in southwestern Gaspesie, Quebec, Canada. Journal of Geochemical Exploration 34, 115145.

Bird, J.M. \& Bussett, W.A. 1980. Evidence of a deep mantle history in terrestrial osmium-iridium-ruthenium alloy. Journal of Geophysical Research 85, 5461-5470.

Bloom, L.B. \& Steele, K.G. 1989. Gold in till: preliminary results from the Matheson area, Ontario. In: DiLabio, R.N.W. \& Coker, W.B. (eds.) Drift Prospecting. Geological Survey of Canada, Paper 89-20, 61-70.

Campbell, J.E. \& Schreiner, B.T. 1989. Quaternary geology and its implications to gold exploration in the LaRonge and Flin Flon domains, Saskatchewan. In: DiLabio, R.N.W. \& Coker, W.B. (eds.) Drift Prospecting. Geological Survey of Canada, Paper 89-20, 113-126.

Clifton, H.E., Hunter, R.E., Swanson, F.J. \& Philips, R.L. 1969. Sample size and meaningful gold analysis. U.S. Geological Survey, Professional Paper 625-C. 17 p.

Cook, J.C. 1997. A comparison of differing lake sediment field sample size: application to geochemical exploration for epithermal gold deposits in central British Columbia. Journal of Geochemical Exploration 60, 127138.

Day, S. \& Fletcher, K. 1986. Particle size and abundance of gold in selected stream sediments, southern British Columbia, Canada. Journal of Geochemical Exploration 26, 203-214.

DiLabio, R.N.W. 1990. Classification and interpretation of the shapes and surface textures of gold grains from till on the Canadian Shield. Geological Survey of Canada, Paper 90-1C, 323-329.

Giusti, L. 1986. The morphology, mineralogy, and behaviour of "fine-grained" gold from placer deposits of Alberta: sampling and implications for mineral exploration. Canadian Journal of Earth Sciences 23, 1662-1672.
Gleeson, C.F., Rampton, V.N., Thomas, R.D. \& Paradis, S. 1989. Effective mineral exploration for gold using geology, Quaternary geology and exploration geochemistry in areas of shallow till. In: DiLabio, R.N.W. \& Coker, W.B. (eds.) Drift Prospecting. Geological Survey of Canada, Paper 89-20, 71-96.

Grant, A.H., Lavin, O.P. \& Nichol, I. 1991. The morphology and chemistry of transported gold grains as an exploration tool. Journal of Geochemical Exploration 40, 73-94.

Groen, J.C., Craig, J.R. \& Rimstidt, J.D. 1990. Gold-rich formation on electrum grains in placers. Canadian Mineralogist 28, 207-228.

Halbauer, D.K. \& Utter, T. 1977. Geochemical morphological characteristics of gold particles from recent rivers and fossil placer of Witwatersrand. Mineralium Deposita 12, 293-306.

Hall, G.E.M., Vaive, J.E., Coope, J.A. \& Weiland, E.F. 1989. Bias in the analysis of geological materials for gold using current methods. Journal of Geochemical Exploration 34, 157-171.

Huhta, P. 1989. Heavy minerals of till in gold prospecting in the Hattu schist belt, Ilomantsi, eastern Finland. Geological Survey of Finland, Special Paper 10, 59-60.

Kinnunen, K.A. 1996. Classification scheme for surface textures of gold nuggets from Finnish Lapland. Bulletin of the Geological Society of Finland 68, 18-33.

Knauf, V.V. \& Sendeev, A.S. 1996. The device for wet separation of loose materials. Pat. 2521 RU 6B03B 5/62 N 2855952/29-33, Bulletin 8, 10.

Knauf, V.V. 1996. On metrological ensuring of mineralogical investigations. Proceedings of Russian Mineral Society CXXV, N 6, 109-113. (in Russian)

Lahtinen, R. \& Lestinen, P. 1996. Background variations of ore-related elements and regional-scale mineralization indications in Palaeoproterozoic bedrock in the Tampere-Hämeenlinna area, southern Finland. Geological Survey of Finland, Bulletin 390. 39 p.

Luukkonen, A. 1994. Main geological features, metallogeny and hydrothermal alteration phenomena of certain gold and gold-tin-tungsten prospects in southern Finland. Geological Survey of Finland, Bulletin 377. 153 p.

Leon, J.S. 1995. Use of placer gold characteristics to locate bedrock gold mineralization. Exploration and Mining Geology 4, 335-339.

Nikkarinen, M. 1991. Size, form and composition of gold grains in glacial drift in Ilomantsi, eastern Finland. Journal of Geochemical Exploration 39, 295-302.

Novgorodova, M.I. 1983. Native metals in the hydrothermal ores. Moscow: Nauka. 287 p. (in Russian)

Nurmi, P.A., Hartikainen, A., Damsten, M. \& Rasilainen, K. 1989. Sampling strategies and pathfinder elements in till and rock geochemical gold exploration, Hattu schist belt, Ilomantsi, eastern Finland. Geological Survey of Finland, Special Paper 10, 53-57.

Outridge, P.M., Doherty, W. \& Gregoire, D.C. 1998. Determination of trace elemental signatures in placer gold by laser ablation-inductively coupled plasma-mass spec- 
trometry as a potential aid for gold exploration. Journal of Geochemical Exploration 60, 229-240.

Saarnisto, M., Tamminen, E. \& Vaasjoki, M. 1991. Gold in bedrock and glacial deposits in the Ivalojoki area, Finnish Lapland. Journal of Geochemical Exploration 39, 303-322.

Stockman, H.W. \& Hlava, P. 1984. Platinum group minerals in alpine chromitites from southwestern Oregon. Economic Geology 79, 491-508.

Urusov, V.S., Tauson, V.L. \& Akimov, V.V. 1997. Solid State Geochemistry. Moscow: GEOS. 500 p. (in Russian)
Vasconcelos, P. \& Kyle, J.R. 1991. Supergene geochemistry and crystal morphology of gold in a semiarid weathering environment: application to gold exploration. Journal of Geochemical Exploration 40, 115-132.

Xie, Xuejing \& Wang, Xueqiu 1991. Geochemical exploration for gold: a new approach to an old problem. In: Rose, A.W. \& Taufen, P.M. (eds.) Geochemical Exploration 1989. Journal of Geochemical Exploration 40, 2548.

Youngson, J.H. \& Craw, D. 1995. Evolution of placer gold deposits during regional uplift, central Otago, New Zeland. Economic Geology 90, 731-745. 